\title{
FORAGING BEHAVIOUR OF AMEGILLA ZONATA (L.) ON OCIMUM KILIMANDSCHARICUM GUERKE
}

\section{DeVINDER Sharma* AND DP ABrol}

\author{
Division of Entomology, 6th Block, Faculty of Agriculture, \\ Sher-e-Kashmir University of Agricultural Sciences and Technology, Chatha, \\ Jammu-180 009 (J\&K) India
}

Key words: Pollinator diversity, Amegilla zonata, Ocimum kilimandscharicum, Foraging, Abiotic factors

\begin{abstract}
Ocimum kilimandscharicum Guerke an important medicinal plant of Jammu and Kashmir, India was found to be pollinated by insects belonging to 4 orders, 8 families and 14 species. The flowers of $O$. kilimandscharicum were visited abundantly by Amegilla zonata (L.) followed by Apis dorsata and A. cerana. The number of bees foraging during different times on the day ranged from 4.7 - 11.30/ 5 plants/5 min; visited 12 - 25 flowers/5 plant and spent 2.3 - 7.9 s/flower. Foraging populations of A.zonata responded significantly to environmental factors.
\end{abstract}

Ocimum kilimandscharicum Guerke (fam.: Lamiaceae, common name Camphor Basil) is an economically important medicinal perennial herb (Dolly et al. 2012) of Jammu and Kashmir. In India, it is being cultivated both in plains and in hilly areas of U.P, West Bengal, Dehradun, Maharashtra, Mysore, Kerala, Jammu and Kashmir and Darjeeling (Singh et al. 1955). It is a good nectar producing plant. The flowers plenty of insect pollinators. The Blue-banded bee, Amegilla zonata (L.) (Hymenoptera: Apidae: Anthophoridae), are medium-large, pubescent, long-tongued, solitary, fossorial bees that nest gregariously in vertical burrows in the ground or horizontally in soil embankments and occasionally in sandstone or artificial substrates (Michener 1960). The Amegilla sp. have already been established as well-known pollinators of a wide range of crops (Dollin et al. 2000, Gross and Kukuk 2001, Hogendoorn et al. 2007).

The pollinator diversity and foraging behaviour of Amegilla zonata (L.) were examined in the University research farm, SKUAST-Jammu of Jammu and Kashmir, India. Counts were made throughout the flowering period of $O$. kilimandrischium. The A. zonata were followed from their first flower visit to a marked area until the bee moved away. The observations were made during 2 hrs periods and within 3 time periods daily from 0900 - 1000, 1200 - 1300 and 1400-1500 hrs local time. During each count, the 5 marked plants were observed for 5 min. Data were gathered on visit rates (number of bee/plant/minute), number of flowers visited/plant and time spent/flower. The data so obtained was analyzed statistically.

It is showed that insects belong to 4 orders, 8 families, and 14 species forag the $O$. kilimandrischium. The abundance of all the insects foragers was in the order of : A. zonata $>A$. dorsata $>A$. mellifera $>A$. cerana $>$ others. The other insect visitors included solitary bees (Xylocopa fenestrata, Halictus sp., Nomia sp.), butterflies (Pieris brassicae, Danaus chrysippus), true flies (Eristalis sp., Metasyrphus sp., Musca domestica), and beetles (blue beetle, Coccinella septempunctata). Honeybees (A. mellifera and A. cerana) were reported as worthy foragers of $O$. kilimandrischium (Free 1993, Sajjanar et al. 2005). Kuberappa et al. (2007) recorded ten species

*Author for correspondence: <devskuastj@gmail.com>. 
of insect pollinators on Vishnu tulsi (O. sanctum [O. tenuiflorum]), belonging to orders Hymenoptera (Apis cerana, A. florea, A. dorsata, Trigona iridipennis, Vespa cincta [V. tropica] and unidentified) and Diptera (including Musca domestica, Lucilia cuprina and Philoliche longitorsis).

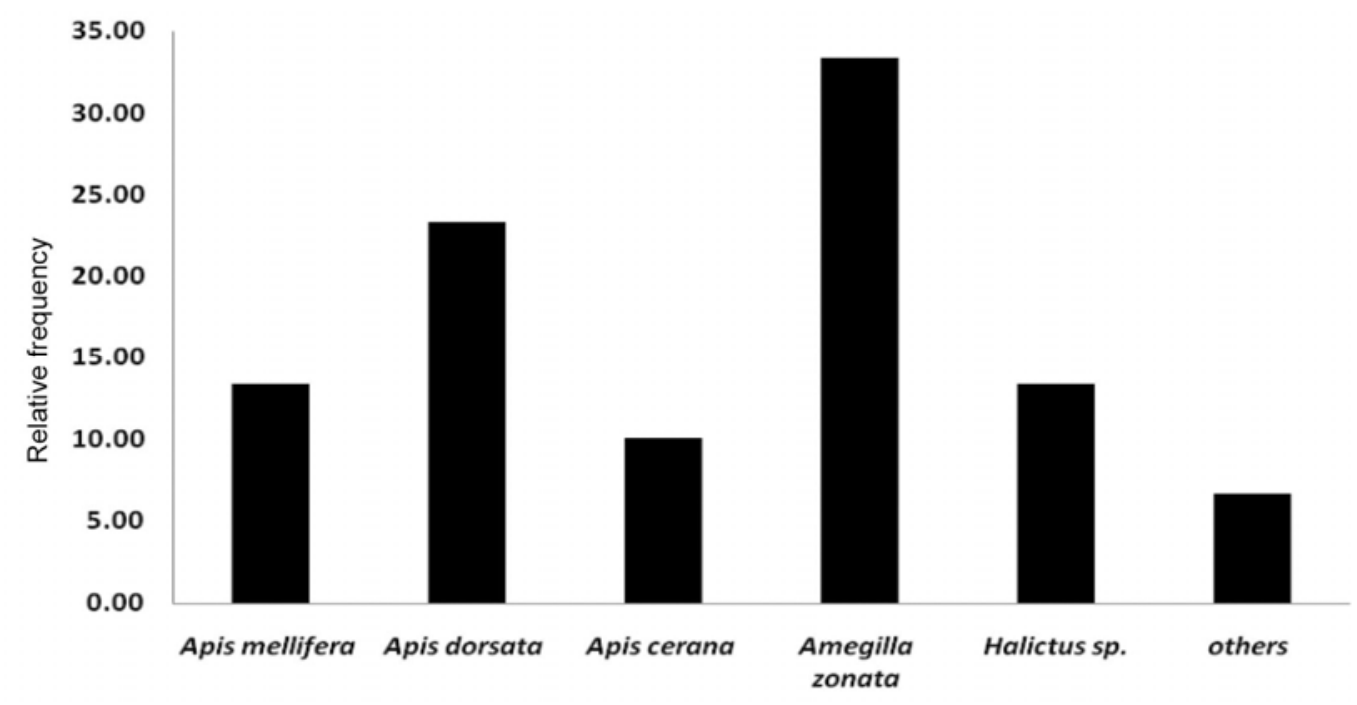

Fig. 1. Abundance of pollinators insects /foraging insects on O. kilimandrischium.

The foraging activity of $A$. zonata revealed that the number of bees foraging during different times on the day ranged between 4.7 and $11.30 / 5$ plants/5 min (Fig. 2). The A. zonata on an average visited 12 - 25 flowers $/ 5$ plant. The amount of time bees take to forage on flower is an important component determining foraging behaviour. The time spent by A. zonata on flower ranged between spent 2.3 and 7.9 s/flower. The highest foraging activity was noticed between 12.00 and 13.00 hrs. Darrah (1974) observed that pollination of O. kilimandscharicum was mostly by honeybees, which preferentially moved to plants within the same cultivar, but some crosspollination between cultivars did occur, especially of cultivars that were represented by a few plants only. Some cross-pollination was also found to occur between species but the resultant seed was not viable.

Of the several factors, abiotic factors greatly influence the foraging behaviour. The foraging behavior is greatly affected by the quantity and quality of resources like pollens or vector and and environmental characteristics. The observations on the abundance of $A$. zonata on blooming $O$. kilimandrischium in relation to abiotic variables revealed that temperature (maximum and minimum) and sunshine exerted a positive and significant effect while relative humidity (maximum and minimum), rainfall and wind speed had a negative impact on $A$. zonata foraging. The number of visiting bees and number of flowers visited by A. zonata on O. kilimandrischium exhibited significant positive correlation with the temperature (maximum) but positive and nonsignificant with temperature (minimum) and sunshine. The relative humidity, rainfall and wind speed had significant negative effect on the foraging activity of $A$. zonata. The duration of time spent per flower was significantly correlated with temperature (maximum and minimum); positive but non significantly with sunshine (Table 1). The relative humidity (maximum) exerted a significant negative effect while as, relative humidity (maximum), rainfall and wind speed had a 
positive but non significant effect on bee activity. The multiple linear regression analysis showed that all the weather parameters ensemble were responsible for 98.10 per cent $\left(\mathrm{R}^{2}\right.$ value) of total variation of the foraging activity. The foraging activity of all honeybee species followed the same general pattern as temperature, light intensity, solar radiation, nectar sugar concentration and inversely with relative humidity (Abrol 2012). Each bee pollinator has specific ecological threshold for foraging activity which differ inter and intra specifically depending upon the level of adaptation of a given species in an environment (Burill and Dietz 1981, Abrol and Kapil 1986). Burill and Dietz (1981) reported that the bee activity increased with temperature but was not affected by relative humidity and vapour pressure.

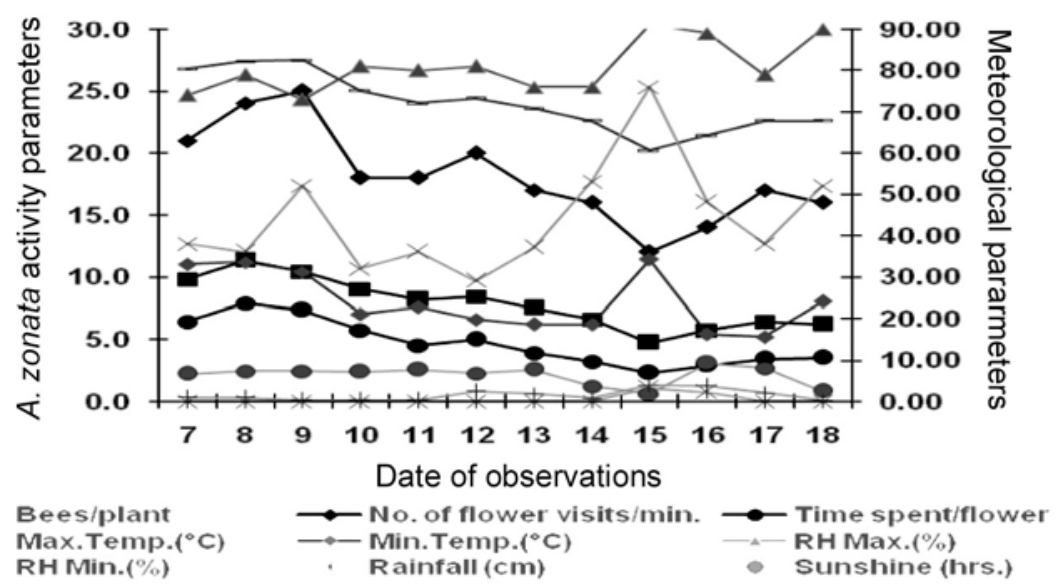

Fig. 2. Effect of abiotic parameters on the foraging activity of A. zonata.

Table 1. Correlation coefficient between population dynamics of $A$. zonata and weather parameters on $O$. kilimandscharicum.

\begin{tabular}{|c|c|c|c|c|c|c|c|}
\hline \multirow{2}{*}{ Parameters } & \multicolumn{2}{|c|}{$\begin{array}{c}\text { Temperature } \\
\left({ }^{\circ} \mathrm{C}\right)\end{array}$} & \multicolumn{2}{|c|}{$\begin{array}{l}\text { Relative humidity } \\
\text { (\%) }\end{array}$} & \multirow[t]{2}{*}{$\begin{array}{l}\text { Rainfall } \\
\text { (cm) }\end{array}$} & \multirow[t]{2}{*}{$\begin{array}{l}\text { Sunshine } \\
\text { (h) }\end{array}$} & \multirow[t]{2}{*}{$\begin{array}{l}\text { Wind } \\
\text { speed }\end{array}$} \\
\hline & Max. & Mini. & Max. & Mini. & & & \\
\hline $\begin{array}{l}\text { Number of bees/ } \\
5 \text { plant }\end{array}$ & $0.986 * *$ & 0.435 & $-0.686^{*}$ & -0.574 & $-0.621^{*}$ & 0.436 & $-0.597^{*}$ \\
\hline $\begin{array}{l}\text { Number of flower } \\
\text { visits/5min. }\end{array}$ & $0.967 * *$ & 0.410 & $-0.704 *$ & -0.492 & $-0.643^{*}$ & 0.406 & $-0.572 *$ \\
\hline Time spent/flower & $0.980 * *$ & $0.525 *$ & $-0.605^{*}$ & -0.477 & $-0.537^{*}$ & 0.380 & $-0.557^{*}$ \\
\hline
\end{tabular}

$\mathrm{P}^{* *}>0.01, \mathrm{p}^{*}>0.05$.

An understanding of the mutualistic relationship between flower-visiting insects and crop species, particularly on the diversity of pollinator species, their spatio-temporal variations, foraging behaviour and their pollination efficiency, is important as they are some of the crucial biological predictors of pollination success. Information on the contribution of wild pollinators to the pollination of flowering crops is mostly lacking. In most areas with crop pollination deficits, bee fauna are sufficiently rich to find suitable target species, and the development of native species should be attempted before considering exotic introductions. The genus Amegilla illustrates the availability of suitable pollinators in large areas of various crops. Hopefully, the knowledge gained 
from these species can be applied to successfully develop other native species and provide improved stability to those crops that rely on insect pollination.

\section{Acknowledgements}

The authors are thankful to Dr. D. P. Abrol, Head, Division of Entomology, SKUAST-Jammu for identification of Amegilla zonata and in conducting the studies.

\section{References}

Abrol DP 2012. Pollination Biology. Biodiversity Conservation and Agricultural Production. Springer Publication, UK. pp. 792.

Abrol DP and Kapil RP 1986. Factors affecting pollination activity of Megachile lanata. Proc. Indian Acad. Sci. (Anim. Sci.) 95: 757-769.

Burill RM and Dietz A 1981. The response of honeybees to variations in solar radiation and temperature. Apidol. 12 : 319-328.

Darrah HE 1974. Investigations of the cultivars of the basil (Ocimum). Econ. Bot. 28(1) : 63-67.

Dollin A, Batley M, Robinson M and Faulkner B 2000. Native bees of the Sydney Region. A Field Guide. Australian Native Bee Research Centre, Richmond, NSW.

Dolly G, Nidhi S, Bos S, Shweta R and Shikha A 2012. Ocimum kilimandscharicum : A systematic review. J. Drug Delivery Therap. 2(3): 45-52 45

Free JB 1993. Insect Pollination of Crops. 2nd Edition, Academic Press, New York. pp. 684.

Gross CL and Kukuk PF 2001. Foraging strategies of Amegilla anomola at the Flowers of Melastoma affine - no evidence for separate feeding and pollinating anthers. In: Benedek P and Richards KW (Eds). Proceedings of the 8th Pollination Symposium. Acta Hort. 56: 171-178.

Hogendoorn K, Coventry S and Keller MA 2007. Foraging behaviour of a blue banded bee, Amegilla chlorocyanea in greenhouses: implications for use as tomato pollinators. Apidol. 38: 86-92.

Kuberappa GC, Shilpa P, Vishwas AB and Vasundara M 2007. Insect pollinators abundance and their activity in Vishnu tulsi, Ocimum sanctum L. Biomed. 2(3): 260-264.

Michener CD 1960. Observations on the behaviour of a burrowing bee (Amegilla) near Brisbane, Queensland (Hymenoptera, Anthophorinae). Queensland Natural. 16: 63-67.

Sajjanar SM, Prabhuswamy HP, Rajagopal D and Kuberappa GC. 2005. Foraging activity and pollinating efficiency of the Indian honeybee, Apis cerana indica in spice basil, Ocimum gratissimum. Adv. Pollen Spore Res. 22: 177-181.

Singh H, Handa KL and Kapoor LD. 1955. Camphor basil raised in Jammu and Kashmir. Ind. J. Pharmacy. 17: 97-98. 